\title{
Chabani Manganyi: Reflecting back on the contemporary possibilities of a liberatory black psychology ${ }^{1}$
}

\section{Chabani Manganyi's memoir, Apartheid and the making} of a Black psychologist is an account of a series of seminal moments in the life of an eminent psychologist and astounding human being. The reader is taken on a journey that tells snippets of his many lives in a country ridden with untold hardships and moments of incredible victory. The versatility of Manganyi's professional endeavours speaks to his many talents, interests and passion for human life. From his clinical and neuropsychology research; the biographies of the renowned South Africans Es'kia Mphahlele, Gerard Sekoto, and Dumile Feni; to his work in apartheid courts; and then on to higher education; Manganyi's life and career are inspirational.

When I was asked to review this book by the editor of PINS, I was excited to be considered for the task. As the title suggests, I was looking forward to reading about the life of a black academic and psychologist in South Africa during Apartheid and to be able to draw inspiration and reflect on how far we might have come; or about the resonances between our experiences as black academics and psychologists in contemporary South Africa and his own. The chapter that captured me the most therefore was the last one, Working for a higher purpose, in which he describes his experiences as Vice Chancellor of the University of Limpopo. In the midst of current unrests across universities in South Africa, it was enlightening to read about Manganyi's successes and challenges as an academic from the mid-1970s through to the 1990s and how many of those battles are still being fought today.

\section{Shose Kessi}

Department of Psychology University of Cape Town Rondebosch

7700 
He starts off this chapter by describing his 10-year stint at the University of the Witwatersrand as a "virtual visiting professor" given the apartheid laws that prevented him from enjoying the status that should have been accorded to an academic of his standing. I wish to tell him that not enough has changed in academia. Black academics are still having to fight for belonging and recognition. Notwithstanding significant improvements in the past few years, much has yet to change too for the students and workers in academic institutions. Having been a member of the Special Executive Task Team at the University of Cape Town (UCT) over the past five months, I have also witnessed the challenges facing senior management in their interactions with students and workers, which resonate with many of the mass emergency meetings that Manganyi describes from Limpopo in the early 1990s.

Aside from his role in transforming the institutional landscape of higher education, Manganyi was first a revolutionary psychologist who also challenged many aspects of the discipline and its practices. This book is a significant testimony to the importance of historical and biographical narratives in guiding our present, but also the deeply political nature of narrative psychology. Chapter Four, Curiosity did not kill this cat, is a highlight of the book for any academic and psychologist. It speaks to how human lives and wellbeing are necessarily intertwined with the social environment. Understanding apartheid through biographical narratives includes the dimension of the unconscious and its relationship with everyday life, how the individual is shaped by but also colludes with systems of racial oppression. Across his body of work, Manganyi has not confined himself to traditional methods and approaches to psychology and instead combines elements of psychoanalysis, fiction, and clinical work in narrating the story of apartheid through the lives of the individuals that he worked with and his own. Manganyi breaks down the barriers of methodological and practical conventions and stresses how knowledge is produced through dialogue and interactions between individuals, disciplines, and art forms. The memoir itself is a powerful piece of writing in which he narrates his own life through the narratives of others.

In this memoir, Manganyi does not delve significantly into his previous theorizing about the black experience although it comes across in each chapter through a carefully crafted conversation between himself, the reader and the lives of those he has written about, assisted in courts, or through his professional experiences in the education sector. Nevertheless, I am curious to know more about Manganyi's views on the relevance of psychology as a discipline, in particular how it relates to the black experience. I was struck, for instance, by some of his accounts of the court cases he attended as an expert witness and how the reliance on psychosocial deficits in black individuals, families and communities made up a significant part of a successful defence. There is no doubt that such arguments were instrumental and responded to the immediacy of the situation, 
however, it would have been interesting given his focus on narratives and the black experience, for him to reflect on the possibilities and limitations of the presentation of black life through the lens of psychological conditions.

Although not framed as such in the book, these reflections on the role and possibilities of psychological work, provide valuable contributions to current discussions on decoloniality in academia. This comes across vividly in his discussion on public interest psychology in Chapter Six, when he states: "It was an opportunity to signal my belief that public interest, the interests of the country's people, should be the foundation stone on which a helpful practice of psychology should be based" (p124). Indeed, this belief becomes even clearer through the narrative of his own life in the opening Chapter, Early days in Mavambe, which sheds some light on his life as a child growing up under apartheid. Testimonies of displacement, poverty, and social alienation coupled with his passion for education and his involvement in student politics give meaning and coherence to his life trajectory and psychology practice.

Throughout the book, the reader gets a sense of Manganyi's character and beliefs, in particular his fearless determination to fight for liberation in South Africa. In doing so, he immerses himself in an interesting space between the conventions of psychology and the structure of the law all the while politicizing a traditionally individual-centred and positivist discipline. His career is an exemplary testament to what psychologists could and should be investing themselves in, even 22 years after the dismantling of apartheid. 